\title{
AgE AND ACCENT - CHANGES IN A SOUTHERN WELSH ENGLISH ACCENT
}

\author{
EDITH PODHOVNIK \\ Edith.Podhovnik@fh-joanneum.at \\ University of Applied Sciences FH Joanneum Graz
}

\begin{abstract}
This paper describes the accent of Neath (South Wales) from a socio-dialectological perspective and deals with changes in the accent which are due to the non-linguistic factor age. In a direct interview with indirect questioning, 27 informants from Neath were recorded for the investigation of the English spoken in Neath. Based on the life-stage approach, the 27 informants are divided into three age-groups, representing adolescents, younger adults, and older adults respectively. The data is described using Well's lexical sets and analysed statistically to show correlations between age and linguistic variants. The percentage with which some variants are realised in the key-words varies by up to 60 per cent. The realisations of STRUT, BATH and START, FACE/STAY, GOAT/SNOW, NEAR, CURE, PLAYER, emPLOYER, FIRE, POWER, and the consonants $/ \mathrm{r} /, / 1 /$, and word final $<$ ing $>$ in participles and gerunds have changed throughout age.
\end{abstract}

Key words: Southern Welsh English, social dialectology, non-linguistic factors, age

Languages have changed and will continue to change. Various factors, like age, gender, education, and ethnicity, might contribute to language change. This paper, sociodialectological in its nature, discusses the non-linguistic factor age and its influence on the accent of Neath.

First, some background information on Neath English (NE) and the survey is given, then socio-dialectology as well as age as a non-linguistic factor are discussed briefly, and, finally, the lexical sets of NE affected most by the factor age are described.

\section{Background}

In the South Wales area, the accents of the following locations have been investigated: Upper Swansea Valley (Thomas, 1984), Swansea (Podhovnik, 1995), the Rhondda Valleys (George, 1990), Port Talbot (Connolly, 1989), Abercrave (Tench, 1989), Pontypridd (Hughes \& Trudgill, 1979), south-east Wales (Wells, 1982b), and, of course, the localities investigated for SAWD (Parry, n.d. [1977]). Resolven is described in further detail in Parry (1999). Walters (1999) looks at the segmental and suprasegmental phonology of the Rhondda Valleys English. Neath English has been analysed phonetically and phonologically by Podhovnik (2008). Penhallurick (2004) gives an overview over Welsh English phonology. 
Neath is a small town in South Wales, situated a few miles away from Swansea. It is situated on the river Neath and has approximately 50,000 inhabitants. Census figures of 1998 (Welsh Office, 1998) say that around a quarter of inhabitants of Neath can speak, read, or write Welsh.

For the investigation of NE, the interviews were conducted at Neath College in 1996 in a direct interview with indirect questioning and recorded with an analogue tape recorder. With the questions of The Short Phonological Questionnaire (Evans et. al, n.d.) and some 30 additional questions, 27 people from Neath were interviewed. The material is available only as analogue recordings.

The informants, who were students, teachers, and support staff at Neath College, are divided into three age-groups, into $16-20$ year-olds, 25 - 40 year-olds, and $45-60$ year-olds.

NE is a typical Southern Welsh English accent. Concerning the dialects having influenced Neath English, three main sources can be identified, namely, first of all, regional and urban English dialects of the West Midlands, Gloucestershire, Somerset, Devon, and Cornwall, secondly, RP, and, thirdly, Welsh (Walters, 2001, pp. 289f.; Penhallurick, 2004, p. 99).

The vowel system of NE looks as follows:

Short vowels: /I, $\varepsilon, \mathrm{a}, \Lambda, \supset, \mathrm{\mho} /$

Long vowels: /i:, e:, $\varepsilon:$, œ:, a:, ॰:, o:, u:/

Diphthongs: /ai, av, oi/

Long vowels followed by schwa: /i:.ə, u:.ə/

Diphthongs followed by schwa: / ai.ə, au.ə, ei.ə, गi.ə/

Unstressed vowels: /i, ə, I/

Below the NE phoneme inventory is given together with Wells's lexical sets. Like in Penhallurick (2004, p. 100), STAY and SNOW are included along with FACE and GOAT respectively to point to a tricky area in the phonemicisation of NE. TUESDAY is included for comparison with GOOSE. As can be seen in Table 1 below, CURE, POWER, FIRE, PLAYER, emPLOYER, and NEAR are disyllabic in their character.

Table 1 - Lexical Sets and NE Phoneme System

\begin{tabular}{|l|l|}
\hline Lexical Set & NE Phoneme \\
\hline KIT & I \\
\hline DRESS & $\varepsilon$ \\
\hline TRAP & $\mathrm{a}$ \\
\hline LOT & o \\
\hline STRUT & $\Lambda$ \\
\hline FOOT & U \\
\hline BATH & a: \\
\hline CLOTH & 0 \\
\hline NURSE & œ: \\
\hline FLEECE & i: \\
\hline FACE & e: \\
\hline STAY & [ei] \\
\hline
\end{tabular}




\begin{tabular}{|c|c|}
\hline Lexical Set & NE Phoneme \\
\hline GOAT & o: \\
\hline SNOW & {$[\mathrm{ou}]$} \\
\hline PALM & $\mathrm{a}:$ \\
\hline THOUGHT & o: \\
\hline GOOSE & $\mathrm{u}:$ \\
\hline PRICE & ai \\
\hline CHOICE & oi \\
\hline MOUTH & $\mathrm{au}$ \\
\hline SQUARE & $\varepsilon:$ \\
\hline START & $\mathrm{a}:$ \\
\hline NORTH & o: \\
\hline FORCE & o: \\
\hline CURE & u:.ə \\
\hline POWER & au.ə \\
\hline FIRE & ai.ə \\
\hline PLAYER & ei.ə \\
\hline emPLOYER & गi.ə \\
\hline NEAR & i:.ə \\
\hline EARS & œ: \\
\hline TUESDAY & {$[\mathrm{IU} \sim \mathrm{u}:]$} \\
\hline happY & $\mathrm{i}$ \\
\hline lettER & $\partial$ \\
\hline horsES & $\mathrm{I}$ \\
\hline
\end{tabular}

FACE/STAY, GOAT/SNOW, and GOOSE/TUESDAY are not easy to categorise. As does Penhallurick (2004, p. 100), NE [e: - ei] and [o: - ou] are categorised under monophthongal /e:/ and /o:/ in a broad generalised phonemicisation which does not give full phonemic status to the vowels for STAY and SNOW.

Though there are clear tendencies for FACE and GOAT words to be monophthongal and STAY and SNOW words to be diphthongal, giving clear phonemic status to the monophthongs is not possible. Monophthongs [e:] and [o:] are not exclusively used in FACE and GOAT words, but also occur in STAY and SNOW words. Likewise, [ei] and [ou] might also occur in FACE and GOAT words. In other words, the situation of [e:- ei] and [o: - ou] is not as hard and clear as it might seem at first glance and phonemisation is tricky.

The pair [u: - Iu] is categorised under monophthongal /u:/. TUESDAY and GOOSE also fall into this tricky area of phonemisation. Despite the fact that TUESDAY and GOOSE have been given phonemic status in other analyses of Welsh English (Collins \& Mees, 2003, p. 160; Penhallurick, 2004, pp. 101f.), the situation of TUESDAY and GOOSE in NE is different. In NE the data does not support the claim that there is a phonemic difference between TUESDAY and GOOSE. 


\section{Social Dialectology and Social Factor Age}

Social dialectology looks at linguistic variables in connection with social variables. According to Upton (2000, pp. 44f.), a study which primarily looks at language variation, but also includes social parameters falls into the sub-category of social dialectology. Social dialectological studies deal with linguistic variables, hence 'dialectological', but, at the same time, offer some insight into societies, hence 'social'.

This paper on the NE accent is socio-dialectological as it discusses the social variable of age and shows to what extent the factor age has an influence on people's accent in Neath.

The social factor age brings with it some difficulties as any division of age is arbitrary. Questions arise of what the differences between these age-groups are and where the boundaries between the age-groups can be put in legitimately.

Eckert (1997, p. 151) talks about life stages and argues that people experience age and aging not only as individuals, but also as part of a cohort of people sharing a life stage and/or an experience of history. Time and its passage are linked more to life events, which include religious, institutional, legal, and physiological events. These events are associated with certain life stages.

As Cheshire (2005, p. 1552) points out, important life events influence the development of language in that they affect the social relations and social attitudes of individuals. Factors interacting with age are aspects of people's identities, lifestyles, and psychobiographies. Age by itself has no explanatory values (Milroy and Gordon, 2003, p. 39).

In general, studies taking a life-course perspective differentiate between the following life stages: childhood, adolescence, young adulthood, middle age, and old age (Eckert, 1997, pp. 154ff.). For the analysis of NE, the informants were divided into three age-groups, namely into 16 - 20 (age-group I), 25- 40 (age-group II), and 45 - 60 (agegroup III) year-olds. This division reflects the life-stages of the informants and could be seen as the life stages of adolescents, younger adults, and older adults.

The age bracket used for the youngest informants has been pre-defined by the school system. At college or in their apprenticeship, people usually fall into a certain age-group. At Neath College the A-level students are older than 16 and younger than 20, and the apprentices, too, fall into the same age-bracket. The other divisions are, of course, somewhat arbitrary. Adolescence is associated with secondary education, while early adulthood and middle age are connected with the workplace (Eckert, 1997, p. 159).

In the study of NE, age turned out to bet the most influential non-linguistic factor influencing the accent. There are differences of up to 60 per cent. The realisations of STRUT, BATH and START, FACE/STAY, GOAT/SNOW, NEAR, CURE, PLAYER, EmPLOYER, FIRE, POWER, and the consonants $/ 1 /$ and $/ \mathrm{r} /$, and the combination of vowel and consonant $/ \mathrm{r} \mathrm{y} /$ alike have changed throughout age.

\section{Lexical Sets Affected by Age}

For the discussion of the influence age has on the realisation of the phonemes, it has to be pointed out that age-group II has only seven informants, while age-groups I and II 
consist of ten informants each. As there is no equal number of informants in each agegroup, the percentages within the groups are calculated. All occurrences within one category amount to 100 per cent, and all figures are calculated within that category. Therefore, the relations of the phoneme's realisations to each other are independent from the number of informants. In the tables below, the percentages are given, and the number of actual occurrences of variables is put in brackets.

In the description below, age-groups I, II, and III are also referred to youngest, middle, and oldest informants respectively.

The lexical sets most affected by the factor age are STRUT, lettER, BATH and START, FACE/STAY, GOAT/SNOW, NEAR, CURE, PLAYER, emPLOYER, FIRE, POWER, and the consonants $/ 1 /$, and $/ \mathrm{r} /$.

The table below shows the percentage of occurrences with which STRUT is realised in NE.

Table 2 - Realisations of STRUT

\begin{tabular}{|c|c|c|c|c|c|c|c|}
\hline & $\Lambda$ & $\Lambda_{+}$ & $\ddot{\Lambda}$ & $\Lambda$ & $\ddot{\ddot{u}}$ & $\partial$ & Total \\
\hline I & $11.5 \%(15)$ & $5.4 \%(7)$ & $35.4 \%(46)$ & $0 \%$ & $30 \%(39)$ & $17.7 \%(23)$ & $100 \%(130)$ \\
\hline II & $5.6 \%(5)$ & $1.1 \%(1)$ & $50 \%(45)$ & $0 \%$ & $28.9 \%(26)$ & $14.4 \%(13)$ & $100 \%(90)$ \\
\hline III & $16.9 \%(22)$ & $3 \%(4)$ & $30.8 \%(40)$ & $3.8 \%(5)$ & $23.1 \%(38)$ & $16.2 \%(21)$ & $100 \%(130)$ \\
\hline
\end{tabular}

As can be seen above, age influences the use of variants of NE STRUT. There are differences of up to 20 per cent between the age-groups. Figures seem to point to a change in language use. Raised centralised $[\ddot{\Lambda}]$, the second most frequent variant, is increasingly used by the younger informants. Overall, $[\ddot{\Lambda}]$ and $[\ddot{\Lambda}]$ are becoming more popular, whereas $[\Lambda]$ is being less frequently used.

The use of [ə] does not really differ between the age-groups. STRUT is realised as [ə] in less than two out of ten occurrences. It is used almost the same by age-groups I and III, but slightly less by age-group II.

The figures for the realisations of variants for lettER look as follows:

Table 3 - Realisations of letteR

\begin{tabular}{|c|c|c|c|c|c|c|c|c|}
\hline & $\partial$ & $\ddot{4}$ & $\ddot{\Lambda}$ & $\Lambda$ & $\Lambda$ & $\ddot{a}$ & $\mathrm{a}$ & Total \\
\hline I & $53.7 \%(102)$ & $43.2 \%(82)$ & $1.1 \%(2)$ & $0 \%$ & $0.5 \%(1)$ & $0.5 \%(1)$ & $1.1 \%(2)$ & $100 \%(190)$ \\
\hline II & $53.4 \%(71)$ & $45.1 \%(60)$ & $0.8 \%(1)$ & $0 \%$ & $0 \%$ & $0 \%$ & $0.8 \%(1)$ & $100 \%(133)$ \\
\hline III & $75.1 \%(142)$ & $22.2 \%(42)$ & $0 \%$ & $0.5 \%(1)$ & $0 \%$ & $0.5 \%(1)$ & $1.6 \%(3)$ & $100 \%(189)$ \\
\hline
\end{tabular}

In the use of variants of NE lettER, there are differences of up to 20 per cent between the age-groups. One fact is quite remarkable: [ə] is used a lot more by the informants of agegroup III than by the informants of the other two age-groups. Three quarters of all occurrences of lettER are [ə] in the oldest age-group. Although [ə] is also used more 
often in the other two age-groups than raised centralised $[\ddot{i}]$, [ə] does not occur strikingly more often. Just over half of all occurrences of lettER are rendered [ə] by the youngest and middle informants.

The figures point to language change that is taking place. [ə] is in the progress of being substituted by raised centralised $[\ddot{i}]$. In the youngest and middle age-groups, the frequency of $[\ddot{i}]$ in lettER doubles from 22 per cent to more than 40 per cent of occurrences. At the same time, the percentage of [ə] in lettER decreases from 75 per cent of occurrences to slightly more than 50 per cent. It seems that [ə] is becoming less popular and $[\ddot{i}]$ is coming into use.

The following tables list, first of all, the percentage of NE variants of BATH and START and, secondly, the distribution of front and back vowels.

Table 4 - Realisations of BATH and START

\begin{tabular}{|l|l|l|l|l|l|l|l|l|l|l|}
\hline & a: & a: & a: & ä: & a: & $\begin{array}{l}\text { a: } \\
\text { ä: }\end{array}$ & a' & ä' & Total \\
\hline I & $\begin{array}{l}60 \% \\
(24)\end{array}$ & & & $\begin{array}{l}5 \% \\
(2)\end{array}$ & $\begin{array}{l}7.5 \% \\
(3)\end{array}$ & $\begin{array}{l}2.5 \% \\
(1)\end{array}$ & $\begin{array}{l}20 \% \\
(8)\end{array}$ & $\begin{array}{l}2.5 \% \\
(1)\end{array}$ & $\begin{array}{l}2.5 \% \\
(1)\end{array}$ & $\begin{array}{l}100 \% \\
(40)\end{array}$ \\
\hline II & $\begin{array}{l}82.1 \% \\
(23)\end{array}$ & & $\begin{array}{l}3.6 \% \\
(1)\end{array}$ & $\begin{array}{l}3.6 \% \\
(1)\end{array}$ & $\begin{array}{l}3.6 \% \\
(1)\end{array}$ & $\begin{array}{l}3.6 \% \\
(1)\end{array}$ & $\begin{array}{l}3.6 \% \\
(1)\end{array}$ & & & $\begin{array}{l}100 \% \\
(28)\end{array}$ \\
\hline III & $\begin{array}{l}72.5 \% \\
(29)\end{array}$ & $\begin{array}{l}2.5 \% \\
(1)\end{array}$ & $\begin{array}{l}2.5 \% \\
(1)\end{array}$ & $\begin{array}{l}7.5 \% \\
(3)\end{array}$ & $\begin{array}{l}5 \% \\
(2)\end{array}$ & & $\begin{array}{l}7.5 \% \\
(3)\end{array}$ & & $\begin{array}{l}2.5 \% \\
(1)\end{array}$ & $\begin{array}{l}100 \% \\
(40)\end{array}$ \\
\hline
\end{tabular}

Table 5 - Realisations of Back and Front Vowels of BATH and START

\begin{tabular}{|l|l|l|}
\hline & Back Vowels & Front Vowels \\
\hline I & $65 \%$ & $35 \%$ \\
\hline II & $89.3 \%$ & $10.7 \%$ \\
\hline III & $85 \%$ & $15 \%$ \\
\hline
\end{tabular}

The difference between the age-groups in the use of variants of BATH and START amounts up to 30 per cent. There seems to be a tendency towards an increased use of front vowel [ä:]. From less than one out of ten occurrences in age-groups III and II, the frequency of [ä:] in BATH and START rises to two out of ten in age-group I. At the same time, [a:] is losing popularity. In age-groups III and II, [a:] occurs in BATH and START in seven out of ten occurrences and eight out of ten respectively, while in age-group I [a:] is used in six out of ten.

The youngest age-group uses fewer back vowels but more front vowels than the other two age-groups in BATH and START. In age-group I, back vowels account for two thirds and front vowels for one third of all occurrences. Yet, back vowels are used by age-group III in more than eight out of ten of all occurrences of BATH and START and by age-group II in nine out of ten. It is remarkable that the percentage of back vowels in BATH and START falls from 89 to 65 per cent throughout age, while the use of front vowels rises from 10 to 35 per cent. 
The tables below give the figures for variants of NE FACE/STAY. First, the different variants are given, then the figures for the distribution of monophthongal and diphthongal realisations are shown.

Table 6 - Realisations of FACE/STAY

\begin{tabular}{|l|c|c|c|c|c|c|c|c|c|c|}
\hline & eI & ei & ei & e:I & e:i & e: & e: & e: & e:: & Total \\
\hline I & $7.5 \%(12)$ & $49.7 \%(79)$ & & & & $1.3 \%(2)$ & $1.9 \%(3)$ & $38.5(61)$ & & $100 \%(159)$ \\
\hline II & $8.9 \%(10)$ & $42 \%(47)$ & $0.9 \%(1)$ & & & & $0.9 \%(1)$ & $47.3 \%(53)$ & & $100 \%(112)$ \\
\hline III & $20.6 \%(33)$ & $43.8 \%(70)$ & & $0.6 \%(1)$ & $2.5 \%(4)$ & & $0.6 \%(1)$ & $30.6 \%(49)$ & $1.2 \%(2)$ & $100 \%(160)$ \\
\hline
\end{tabular}

Table 7 - Realisations of Diphthongs and Monophthongs in FACE/STAY

\begin{tabular}{|l|l|l|l|}
\hline & I & II & III \\
\hline Diphthongs & $55.5 \%$ & $51.8 \%$ & $67.5 \%$ \\
\hline Monophthongs & $41.5 \%$ & $48.2 \%$ & $32.5 \%$ \\
\hline
\end{tabular}

The percentages with which variants are used in FACE/STAY differ between the agegroups by up to 20 per cent. The use of [ei], the most frequent variant in the middle and old age-groups, increases throughout age. The figures could point to [ei] becoming more popular for the young informants. While [ei] in FACE/STAY accounts for just more than four out of ten of all occurrences in age-groups III and II, it is used in almost half of all occurrences in age-group I.

The second most frequent variant, [e:], too, is used to a different extent in the agegroups. While age-group III realises FACE/STAY as [e:] in three out of ten occurrences, age-groups II and I use [e:] in almost five and four out of ten respectively. Age-group II uses [e:] in FACE/STAY in almost half of all occurrences. For the age-group II, [e:] is the most popular variant.

When all monophthongal and all diphthongal forms are added, the following picture emerges. There seems to be a trend towards monopthongal forms in FACE/STAY. While the frequency of monophthongal forms increases, diphthongal forms seem to lose their popularity throughout age. In NE FACE/STAY, the oldest informants use monophthongal forms in about one third, the middle informants in one half, and the youngest informants in between one third to one half of all occurrences.

The figures show that the oldest informants realise FACE/STAY as diphthongal forms the most, namely in just more than two thirds of all occurrences, whereas the youngest informants use them less, somewhere between two thirds and one half. The overall trend seems to point towards a decrease of diphthongal forms. 
The figures for GOAT/SNOW are given in the tables below.

Table 8 - Realisations of GOAT/SNOW

\begin{tabular}{|c|c|c|c|c|c|c|c|c|c|c|c|c|}
\hline $\mathrm{OU}$ & $\mathrm{ou}$ & $0 . U$ & o'u & $0: \cup$ & o: & $\mathrm{o}:{ }^{\mathrm{u}}$ & o: & Q: & $\mathrm{O}^{\prime}$ & 0 & Ö & Total \\
\hline \begin{tabular}{l|l} 
I & $\begin{array}{l}5.7 \% \\
(9)\end{array}$ \\
\end{tabular} & $\begin{array}{l}35.8 \% \\
(57)\end{array}$ & & & $\begin{array}{l}0.6 \% \\
(1)\end{array}$ & $\begin{array}{l}1.3 \% \\
(2)\end{array}$ & $\begin{array}{l}3.8 \% \\
(6)\end{array}$ & $\begin{array}{l}50.9 \% \\
(81)\end{array}$ & & $\begin{array}{l}0.6 \% \\
(1)\end{array}$ & $\begin{array}{l}0.6 \% \\
(1)\end{array}$ & $\begin{array}{l}0.6 \% \\
(1)\end{array}$ & $\begin{array}{l}100 \% \\
(159)\end{array}$ \\
\hline \begin{tabular}{|l|l|} 
II & $\begin{array}{l}3.6 \% \\
(4)\end{array}$ \\
\end{tabular} & $\begin{array}{l}31.5 \% \\
(35)\end{array}$ & & \begin{tabular}{|l|}
$1.8 \%$ \\
$(2)$ \\
\end{tabular} & & $\begin{array}{l}2.7 \% \\
(3)\end{array}$ & $\begin{array}{l}0.9 \% \\
(1)\end{array}$ & $\begin{array}{l}55 \% \\
(61)\end{array}$ & $\begin{array}{l}0.9 \% \\
(1)\end{array}$ & & $\begin{array}{l}3.6 \% \\
(4)\end{array}$ & & $\begin{array}{l}100 \% \\
(111)\end{array}$ \\
\hline III $\begin{array}{l}20.3 \% \\
(32)\end{array}$ & $\begin{array}{l}24.1 \% \\
(38)\end{array}$ & $\begin{array}{l}1.9 \% \\
(3)\end{array}$ & & $\begin{array}{l}0.6 \% \\
(1)\end{array}$ & $\begin{array}{l}2.5 \% \\
(4)\end{array}$ & $\begin{array}{l}4.4 \% \\
(7)\end{array}$ & $\begin{array}{l}45.6 \% \\
(72)\end{array}$ & & & $\begin{array}{l}0.6 \% \\
(1)\end{array}$ & & $\begin{array}{l}100 \% \\
(158)\end{array}$ \\
\hline
\end{tabular}

Table 9 - Realisations of Diphthongs and Monophthongs in GOAT/SNOW

\begin{tabular}{|l|l|l|l|}
\hline & I & II & III \\
\hline Diphthongs & $42.1 \%$ & $36.9 \%$ & $46.8 \%$ \\
\hline Monophthongs & $57.9 \%$ & $63.1 \%$ & $53.2 \%$ \\
\hline
\end{tabular}

The differences in the use of realisations of GOAT/SNOW between the age-groups vary by up to 15 per cent. Overall there is an increase of [o:], the most frequently used variant. [o:] is realised in less than one half of all occurrences by the oldest, in more than one half by the middle, and in exactly one half by the youngest informants.

The use of the second most frequent variant, [ou], increases throughout age. Whereas the oldest informants realise GOAT/SNOW as [ou] in about one quarter, the middle and youngest informants use [ou] in one third of all occurrences. It seems as if [ou] is becoming more popular.

When some variants become more popular, the frequency of others decreases. This can be seen at the example of [ov], the third most frequent variant. The use of [ou] decreases from the oldest to the youngest informants. Although, strictly speaking, the frequency does not describe a straight line but a curve, there is a sharp decline throughout age. Whereas [ov] is realised in one fifth of all occurrences by age-group III, it is hardly used by the other two age-groups.

The development of the diphthongs is interesting in that a change seems to be in progress. [ov] is seemingly being replaced by [ou]. While the use of [ov] is decreasing throughout age, [ou] is becoming more popular in the younger age-groups.

What all three age-groups have in common is that monophthongal forms are more popular than diphthongal forms. In all three age-groups, monophthongal forms account for more than half of all occurrences in GOAT/SNOW. Monophthongal are becoming more popular. The oldest informants realise monophthongal forms in just more than one half of all occurrences, the middle informants in more than six out of ten, and the youngest informants in almost six out of ten.

Overall diphthongal forms become less popular. Whereas the oldest informants realise diphthongal forms in less than half of occurrences in GOAT/SNOW, the middle informants use them in just more than one third, and the youngest informants in four out of ten. 
NEAR has a disyllabic character. Phonotactic rules of NE do not allow for a schwa to directly follow a vowel. Instead, a syllable break is inserted after the vowel before the second syllable. For NEAR the figures look as follows.

Table 10 - Realisations of NEAR

\begin{tabular}{|c|c|c|c|c|c|c|c|c|c|c|}
\hline & i:ə & i'.ə & I:.2 & i:.ə & $i: . \ddot{~}$ & i:jä & i.ə & i’ว & I.ə & Total \\
\hline $\mathrm{I}$ & $5 \%(1)$ & $10 \%(2)$ & & $45 \%(9)$ & $25 \%(5)$ & $15 \%(3)$ & & & & $100 \%(20)$ \\
\hline II & & & $7.1 \%(1)$ & $14.3 \%(2)$ & $78.6 \%(11)$ & & & & & $100 \%(14)$ \\
\hline III & & & $5 \%(1)$ & $70 \%(14)$ & $5 \%(1)$ & & $5 \%(1$ & $10 \%(2$ & $5 \%(1$ & $100 \%(20)$ \\
\hline
\end{tabular}

Table 11 - Realisation of Second Syllable in NEAR

\begin{tabular}{|c|c|c|c|}
\hline & I & II & III \\
\hline Second syllable [ə] & $40 \%$ & $21.4 \%$ & $75 \%$ \\
\hline Second syllable $[\ddot{\Lambda}]$ & $60 \%$ & $78.6 \%$ & $25 \%$ \\
\hline
\end{tabular}

Age influences the use of variants in NE NEAR. There are differences in the use of [i:.ə] and [i:. $\ddot{\Lambda}]$ of up to 60 per cent. Especially age-group II differs a lot from the other two age-groups.

While [i:.ə] is used most by age-groups I and III, it comes only second in terms of frequency in age-group II. The oldest informants use [i:.ə] in NEAR in almost three out of four occurrences, the youngest informants in just one half. The middle informants realise NEAR as [i:.ə] in just one or two out of ten occurrences.

Hand in hand with the development of [i:.ə], there is a change in the frequency of [i:.̈̈]. While age-group III hardly use [i:.̈] $[i: . \ddot{L}]$ in eight out of ten occurrences. The youngest age-group use it in one quarter of all occurrences.

When looking at the second syllable in NEAR, some variation due to age can be observed. For [ə], there is a remarkable variation between the age-groups. [ə] seems to be most popular in the oldest age-group, which uses [ə] in three quarters of all occurrences of NEAR. Compared to age-group III, the percentage of occurrences of [ə] in the second syllable of NEAR in the middle age-group seems very small with one fifth of all occurrences. In age-group I, the frequency of [ə] is at four out of ten of all occurrences.

As far as raised centralised $[\ddot{i}]$ in the second syllable is concerned, the opposite development to the one of [ə] can be observed. The oldest informants use raised centralised $[\ddot{i}]$ in the second syllable of NEAR in about one quarter of all occurrences, whereas the middle informants realise it in eight out of ten and the youngest informants in six out of ten. The curve the frequency of $[\ddot{\Lambda}]$ in NEAR describes has a peak markedly different from either side. 
NE CURE has a disyllabic character. The figures are given below.

Table 12 - Realisations of CURE

\begin{tabular}{|c|c|c|c|c|c|c|c|c|c|}
\hline & Uə & U.2 & U. & u:ว & u.:. & $\mathrm{u}: \ddot{\mathrm{\Lambda}}$ & u.ä & u'. & Total \\
\hline I & & & $5 \%(1)$ & & $10 \%(2)$ & $80 \%(16)$ & & $5 \%(1)$ & $\begin{array}{l}100 \% \\
(19)\end{array}$ \\
\hline II & & & & & $7.1 \%(1)$ & $\begin{array}{l}92.9 \% \\
(13)\end{array}$ & & & $\begin{array}{l}100 \% \\
(14)\end{array}$ \\
\hline III & $10 \%(82)$ & $10 \%(2)$ & $5 \%(1)$ & $10 \%(2)$ & $25 \%(5)$ & $35 \%(7)$ & $5 \%(1)$ & $5 \%(1)$ & $\begin{array}{l}100 \% \\
(20)\end{array}$ \\
\hline
\end{tabular}

As the table above shows there are differences due to age of up to 60 per cent. [u:.: $]$ is becoming a lot more popular for the young and middle informants. While age-group III uses $[\mathrm{u}: \ddot{\mathrm{\Lambda}}]$ in only one third of all occurrences, age group II realises it in nine out of ten and age-group I in eight out of ten. Occurrences of [u:.̈̈] more than double in age-groups II and I. The informants of these two groups uses [u..:̈] in CURE almost exclusively.

The second most popular variant of CURE, [u:.ə], is being used less. While [u:.ə] accounts for a quarter of all occurrences in the oldest age-group, it is used by the middle and youngest informants in one out of ten and less.

NE player has a disyllabic character and is realised in NE as follows:

Table 13 - Realisations of PLAYER

\begin{tabular}{|c|c|c|c|c|c|c|c|c|c|c|c|c|}
\hline & еюә & eI.ə & ei.ə & ei.̈̈ & erjə & егї̈ & eijə & eiju & eijü & eijä & e:.ə & Total \\
\hline I & & $\begin{array}{l}5 \% \\
(1)\end{array}$ & $\begin{array}{l}25 \% \\
(5)\end{array}$ & & & & $\begin{array}{l}20 \% \\
(4)\end{array}$ & $\begin{array}{l}5 \% \\
(1)\end{array}$ & $\begin{array}{l}40 \% \\
(8)\end{array}$ & & $\begin{array}{l}5 \% \\
(1)\end{array}$ & $\begin{array}{l}100 \% \\
(20)\end{array}$ \\
\hline II & & & $\begin{array}{l}14.3 \% \\
\text { (2) }\end{array}$ & $\begin{array}{l}14.3 \% \\
(2)\end{array}$ & $\begin{array}{l}7.1 \% \\
(1)\end{array}$ & $\begin{array}{l}7.1 \% \\
(1)\end{array}$ & $\begin{array}{l}21.4 \% \\
\text { (3) }\end{array}$ & & $\begin{array}{l}35.7 \% \\
(5)\end{array}$ & & & $\begin{array}{l}100 \% \\
(14)\end{array}$ \\
\hline III & $\begin{array}{l}10 \% \\
(2)\end{array}$ & $\begin{array}{l}10 \% \\
\text { (2) }\end{array}$ & $\begin{array}{l}20 \% \\
\text { (4) }\end{array}$ & & $\begin{array}{l}10 \% \\
(2)\end{array}$ & & $\begin{array}{l}15 \% \\
\text { (3) }\end{array}$ & & $\begin{array}{l}30 \% \\
(6) \\
\end{array}$ & $\begin{array}{l}5 \% \\
(1) \\
\end{array}$ & & $\begin{array}{l}100 \% \\
(20)\end{array}$ \\
\hline
\end{tabular}

Table 14 - Realisations of [.] and [j] in PLAYER

\begin{tabular}{|l|l|l|l|}
\hline & I & II & III \\
\hline$[]$. & $35 \%$ & $28.6 \%$ & $30 \%$ \\
\hline$[\mathrm{j}]$ & $65 \%$ & $71.3 \%$ & $60 \%$ \\
\hline
\end{tabular}

Table 15 - Realisation of Second Syllable in PLAYER

\begin{tabular}{|l|l|l|l|}
\hline & I & II & III \\
\hline$[ə]$ & $55 \%$ & $42.8 \%$ & $65 \%$ \\
\hline$[\ddot{\Lambda}]$ & $40 \%$ & $57.1 \%$ & $30 \%$ \\
\hline
\end{tabular}


[eijü] is becoming more popular. From being realised in three out of ten occurrences in age-group III, [eijï] rises steadily in its frequency to four out of ten in age-group I. The figures show an increase by 10 per cent throughout the age-groups. [ei.ə] and [eijə] are losing popularity.

When the figures are added according to how the second syllable of NE PLAYER is realised, the differences between the age-groups are bigger. [ $[\ddot{i}]$ is used in PLAYER in three out of ten occurrences by the oldest informants, in six out of ten by the middle, and in four out of ten by the youngest age-group. [ə] in PLAYER accounts for more than six out of ten occurrences in the oldest age-group, for four out of ten in the middle agegroup, and for five out of ten in the youngest age-group.

As far as the insertion of syllable break [.] or semi-vowel [j] between the first and the second syllables of PLAYER is concerned, there, too, is a difference. For all age-groups, the semi-vowel [j] is a lot more popular than the syllable break [.]. [j] is inserted in two out of three occurrences by age-group I, but in three out of four by age-group II, and in almost two out of three by age-group III.

NE emPLOYER is disallybic and is realised as follows:

Table 16 - Realisations of emPLOYER

\begin{tabular}{|c|c|c|c|c|c|c|c|c|c|}
\hline & गІР & गІ.ә & गі.ə & गi. & गгјә & oijə & oijü & sijä & Total \\
\hline I & & & $25 \%(5)$ & & & $\begin{array}{l}65 \% \\
(13)\end{array}$ & $10 \%(2)$ & & $\begin{array}{l}100 \% \\
(20)\end{array}$ \\
\hline II & & & $\begin{array}{l}14.3 \% \\
\text { (2) }\end{array}$ & $\begin{array}{l}14.3 \% \\
(2)\end{array}$ & & $\begin{array}{l}57.1 \% \\
(8)\end{array}$ & $\begin{array}{l}14.3 \% \\
(2)\end{array}$ & & $\begin{array}{l}100 \% \\
(14)\end{array}$ \\
\hline III & $\begin{array}{l}10 \% \\
\text { (2) }\end{array}$ & $\begin{array}{l}10 \% \\
\text { (2) }\end{array}$ & $30 \%(6)$ & & $\begin{array}{l}5 \% \\
(1)\end{array}$ & $25 \%(5)$ & $15 \%(3)$ & $\begin{array}{l}5 \% \\
(1)\end{array}$ & $\begin{array}{l}100 \% \\
(20)\end{array}$ \\
\hline
\end{tabular}

The factor age has an effect on the choice of variants of emPLOYER with differences of up to 40 per cent. The most frequently used variant, [oijə], shows a steady increase throughout age. From one quarter of all occurrences, the frequency of [oijə] increases to more than one half in age-group II up to almost two thirds in age-group I. [oijo] is realised more than twice as often by the younger age-groups than by the oldest. Since there is a steady increase of the form, this could be a sign for language change.

[əi.ə], the second most frequent variant, also shows some variation between the agegroups. In age-group III, emPLOYER is realised as [oi.ə] in almost one third of occurrences, but only in one quarter in age-group I.

When the variants are grouped together according to the realisation of the second syllable and to the insertion of a syllable break or a semi-vowel, the following picture emerges. For all three age-groups alike, [ə] is the most popular realisation of the second syllable of emPLOYER, although there are differences between the age-groups. In agegroup III, [ə] accounts for eight out of ten of all occurrences, for age-group II in seven out of ten, and for age-group I in nine out of ten.

Looking at the insertion of syllable break [.] or semi-vowel [j], there seems to be a clear trend towards an increase in the case of [j] and a decrease in the case of [.]. The semi-vowel is becoming more popular throughout age, whereas the syllable break is losing popularity. 
NE FIRE is disyllabic. The tables below show the realisations of FIRE.

Table 17 - Realisations of FIRE

\begin{tabular}{|l|l|l|l|l|l|l|l|l|l|l|l|}
\hline & ai $^{\text {2 }}$ & aІə & aІə & aiə & aI.ə & ai.ə & äi.ə & aijə & aijə & aijü & Total \\
\hline I & & & & $\begin{array}{l}2.1 \% \\
(1)\end{array}$ & & $\begin{array}{l}6.3 \% \\
(3)\end{array}$ & & $\begin{array}{l}47.9 \% \\
(23)\end{array}$ & $\begin{array}{l}2.1 \% \\
(1)\end{array}$ & $\begin{array}{l}41.7 \% \\
(20)\end{array}$ & $\begin{array}{l}100 \% \\
(48)\end{array}$ \\
\hline II & & & & & & $\begin{array}{l}5.7 \% \\
(2)\end{array}$ & $\begin{array}{l}51.4 \% \\
(18)\end{array}$ & $\begin{array}{l}2.9 \% \\
(1)\end{array}$ & $\begin{array}{l}40 \% \\
(14)\end{array}$ & $\begin{array}{l}100 \% \\
(35)\end{array}$ \\
\hline III & $\begin{array}{l}2.2 \% \\
(1)\end{array}$ & $\begin{array}{l}8.7 \% \\
(4)\end{array}$ & $\begin{array}{l}2.2 \% \\
(1)\end{array}$ & $\begin{array}{l}2.2 \% \\
(1)\end{array}$ & $\begin{array}{l}2.2 \% \\
(1)\end{array}$ & $\begin{array}{l}30.4 \% \\
(14)\end{array}$ & $\begin{array}{l}2.2 \% \\
(1)\end{array}$ & $\begin{array}{l}32.6 \% \\
(15)\end{array}$ & $\begin{array}{l}7.4 \% \\
(8)\end{array}$ & $\begin{array}{l}100 \% \\
(46)\end{array}$ \\
\hline
\end{tabular}

Table 18 - Realisations of [.], [j], and Zero in FIRE

\begin{tabular}{|l|l|l|l|}
\hline & I & II & III \\
\hline$[]$. & $6.3 \%$ & $5.7 \%$ & $30.4 \%$ \\
\hline$[\mathrm{j}]$ & $91.7 \%$ & $94.3 \%$ & $40 \%$ \\
\hline Zero & $2.1 \%$ & $0 \%$ & $15.3 \%$ \\
\hline
\end{tabular}

Table 19 - Realisations of Second Syllable in FIRE

\begin{tabular}{|c|c|c|c|}
\hline & $\mathrm{I}$ & II & III \\
\hline Sec & $58.4 \%$ & $60 \%$ & $82.7 \%$ \\
\hline Second syllable $[\ddot{\Lambda}]$ & $41.7 \%$ & $40 \%$ & $7.4 \%$ \\
\hline
\end{tabular}

The factor age plays an important role in the informants' choice of a certain variant of NE FIRE. The differences amount up to 50 per cent. The frequencies with which [aijə], [aijï], and [ai.ə] are used by informants of different age-groups describe certain trends. What all three variants have in common is the fact that the main differences are found between age-groups I and II, on the one hand, and age-group III, on the other hand.

[aijə] is the overall most frequently used variant of NE FIRE. While age-group III use [aijo] in FIRE in three out of ten occurrences, age-group II realise NE FIRE as [aijə] in five out of ten occurrences and age-group I in four out of ten. The general trend is for [aijo] to become more popular.

[aijï], too, becomes more popular in the younger age-groups. The frequency rises from a use in one out of ten occurrences in age-group III to four out of ten in age-groups II and I. For [aijü] the frequency rises sharply between age-groups II and III. The difference in the use of [aijï] in FIRE between age-groups II and III is a remarkable 33 per cent.

The overall increase of [aijə] and [aijü] in FIRE goes hand in hand with a decrease of [ai.ə], which is overall the third most frequent variant. The frequency of [ai.ə] decreases from a use of three out of ten occurrences in age-group III to less than one out of ten for age-groups II and I. The figures indicate that [ai.ə] is becoming a lot less popular. 
For the realisation of the second syllable of FIRE, all age-groups prefer [ə], although the frequency changes remarkably. It seems that [ə] is losing its popularity and is being replaced by $[\ddot{i}]$. The use of $[ə]$ in the second syllable of FIRE decreases from age-group III to age-group I from eight out of ten occurrences to six out of ten and less.

Hand in hand with the decrease of [ə], there is an increase of raised centralised [ $\ddot{\Lambda}]$ in the second syllable of FIRE. Age-group III use raised centralised $[\ddot{i}]$ in less than one out of ten occurrences, while age-groups I and II realised it in four out of ten. The frequency of $[\ddot{i}]$ increases sharply from age-group III to age-group I. In other words, $[\ddot{i}]$ in the second syllable of FIRE is used almost six times more often by the youngest and middle informants than by the oldest informants.

Grouping the variants together according to whether a syllable break or semi-vowel is inserted after the first syllable of FIRE presents another difference due to age. The frequency of [.] decreases sharply, while the use of [j] increases remarkably. In agegroup III, [.] amounts to almost one third of all occurrences, whereas, for age-groups I and II, it accounts for less than one out of ten. [ə] is, thus, changing from being regularly used to being hardly used.

The decrease of the syllable break is accompanied by a substantial increase of the semi-vowel in FIRE. The use of [j] more than doubles from age-group III to age-groups I and II. The youngest and middle informants use the semi-vowel [j] in FIRE in more than 90 per cent of all occurrences, while the oldest informants use [j] in 40 per cent.

Judging from the figures mentioned above, a change seems to have taken place. The syllable break [.], which still accounts for almost one third of all occurrences in agegroup III, has been or is being replaced by the semi-vowel [j].

NE POWER is disyllabic. The figures for the realisation of POWER are given below.

Table 20 - Realisations of POWER

\begin{tabular}{|c|c|c|c|c|c|c|c|c|c|c|c|c|c|c|}
\hline & avə & $\begin{array}{c}\text { av. } \\
\partial\end{array}$ & ąu.ə & $\begin{array}{c}\text { av. } \\
\ddot{\Lambda}\end{array}$ & au.ə & au. & $\begin{array}{c}\mathrm{au}^{\mathrm{w}} \\
\partial\end{array}$ & auwə & $\begin{array}{c}\text { auw } \\
\Lambda \\
\end{array}$ & $\begin{array}{c}\text { auw } \\
\ddot{\Lambda} \\
\end{array}$ & $\begin{array}{c}\text { auw } \\
\text { aut } \\
\ddot{\Lambda}\end{array}$ & $\begin{array}{c}\text { auw } \\
\text { ä }\end{array}$ & $\begin{array}{c}\text { auw } \\
\text { o } \\
\end{array}$ & \begin{tabular}{|c|} 
Tota \\
1
\end{tabular} \\
\hline I & & & $\begin{array}{l}2 \% \\
(1)\end{array}$ & & $\begin{array}{l}38.8 \\
\% \\
(19)\end{array}$ & $\begin{array}{l}2 \% \\
\text { (1) }\end{array}$ & $\begin{array}{l}2 \% \\
\text { (1) }\end{array}$ & $\begin{array}{l}42.9 \\
\% \\
(21)\end{array}$ & $\begin{array}{l}2 \% \\
(1)\end{array}$ & $\begin{array}{l}10.2 \\
\% \\
(5)\end{array}$ & & & & $\begin{array}{l}100 \\
\% \\
(49)\end{array}$ \\
\hline II & & & $\begin{array}{l}5.9 \\
\% \\
(2)\end{array}$ & & $\begin{array}{l}35.3 \\
\% \\
(12)\end{array}$ & $\begin{array}{l}8.8 \\
\% \\
(3)\end{array}$ & $\begin{array}{l}5.9 \\
\% \\
(2)\end{array}$ & $\begin{array}{l}35.3 \\
\% \\
(12)\end{array}$ & & $\begin{array}{l}8.8 \% \\
\text { (3) }\end{array}$ & & & & $\begin{array}{l}100 \\
\% \\
(34)\end{array}$ \\
\hline \begin{tabular}{|l|} 
II \\
I
\end{tabular} & $\begin{array}{l}14 \\
\% \\
(7)\end{array}$ & $\begin{array}{l}2 \% \\
\text { (1) }\end{array}$ & $\begin{array}{l}6 \% \\
(3)\end{array}$ & $\begin{array}{l}2 \% \\
\text { (1) }\end{array}$ & $\begin{array}{l}52 \% \\
(26)\end{array}$ & & $\begin{array}{l}6 \% \\
\text { (3) }\end{array}$ & $\begin{array}{l}10 \% \\
(5)\end{array}$ & $\begin{array}{l}2 \% \\
(1)\end{array}$ & & $\begin{array}{l}2 \% \\
\text { (1) }\end{array}$ & $\begin{array}{l}2 \% \\
\text { (1) }\end{array}$ & $\begin{array}{l}2 \% \\
\text { (1) }\end{array}$ & $\begin{array}{l}100 \\
\% \\
(50)\end{array}$ \\
\hline
\end{tabular}


Table 21 - Realisations of [.], [w], and Zero in POwER

\begin{tabular}{|l|l|l|l|}
\hline & I & II & III \\
\hline$[]$. & $42.8 \%$ & $50 \%$ & $62 \%$ \\
\hline$[\mathrm{w}]$ & $57.1 \%$ & $50 \%$ & $24 \%$ \\
\hline Zero & $0 \%$ & $0 \%$ & $14 \%$ \\
\hline
\end{tabular}

Table 22 - Realisations of Second Syllable in POWER

\begin{tabular}{|l|l|l|l|}
\hline & I & II & III \\
\hline$[$ ə] & $85.7 \%$ & $80.4 \%$ & $92 \%$ \\
\hline$[\ddot{\perp}]$ & $12.2 \%$ & $35.3 \%$ & $10 \%$ \\
\hline
\end{tabular}

There are differences of up to 20 per cent that can be attributed to age. The two most frequently used variants, [au.ə] and [auwə], are interesting in that they show different trends. [au.ə] is becoming less and [auwə] more popular through age.

As opposed to [au.ə], the figures for [auwə] show an increase, not an overall decrease. From a use of one out of ten occurrences in age-group III, [auwə] is used in about one third in age-group II and accounts for roughly four out of ten in age-group I. Thus, the younger the informants become, the more likely they are to realise NE POWER as [auwa].

The figures of Table 4.25 show another interesting fact, namely that the order of the overall most frequently used variants is not the same in all three age-group. In the oldest age-group, [au.ə] is the most frequent variant, [avə] is second in terms of frequency, and [auwə] comes third. The middle informants realise POWER as [au.ə] and [auwə] to exactly the same extent. Both variants are used in about one third of all occurrences. In the youngest age-group, the most popular variant is [auwə], and the second most frequent variant is [au.ə].

When all variants of POWER are added according to the type of insertion and to the realisation of the second syllable as [ə] or $[\ddot{\Lambda}]$, certain differences due to age become visible. As far as the insertion of syllable break or semi-vowel in POWER is concerned, there seems to be a change in progress. [.] is seemingly on its way out, and [w] is coming more and more into use. The frequency of $[\mathrm{w}]$ actually doubles from the oldest to the youngest informants. The semi-vowel in POWER [w] increases steadily throughout age, whereas the syllable break [.] decreases.

The figures differ for the realisation of the second syllable of POWER. What all three age-groups have in common is that they realise the second syllable of POWER most frequently as [ə]. To which extent [ə] occurs varies slightly, however. Nine out of ten of all occurrences are [ə] in age-group III and eight out of ten in age-group II. Age-group I uses [ə] in the second syllable of POWER in between eight and nine out of ten of all occurrences.

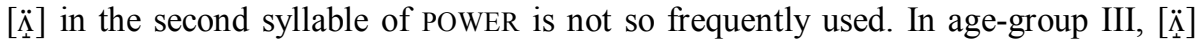
accounts for less than one out of ten occurrences, in age-group II for almost two out of ten, and for age-group I in one out of ten. 
The figures for the realisation of $\mathrm{NE} / \mathrm{l} /$ are given in the table below.

Table 23 - Realisations of /1/

\begin{tabular}{|l|l|l|l|}
\hline & 1 & t & Total \\
\hline I & $86.2 \%(94)$ & $13.8 \%(15)$ & $100 \%(109)$ \\
\hline II & $100 \%(76)$ & & $100 \%(76)$ \\
\hline III & $94.4 \%(106)$ & $3.6 \%(4)$ & $100 \%(110)$ \\
\hline
\end{tabular}

Due to the factor age, there are some differences. Between the age-groups, the use of clear [1] and dark [ 1$]$ in final position varies. The difference between the age-groups equals ten per cent. There is no occurrence of dark [ł] at all in age-group II. The youngest informants used [ 1$]$ in one out of ten occurrences, while the oldest realised it only half as often.

Below the figures are given for $\mathrm{NE} / \mathrm{r} /$ in initial position.

Table 24 - Realisations of /r/ in Initial Position

\begin{tabular}{|l|l|l|l|}
\hline & I & I & Total \\
\hline I & $86.3 \%(69)$ & $13.7 \%(11)$ & $100 \%(80)$ \\
\hline II & $85.7 \%(48)$ & $14.3 \%(8)$ & $100 \%(56)$ \\
\hline III & $88.8 \%(71)$ & $11.2 \%(9)$ & $100 \%(80)$ \\
\hline
\end{tabular}

As far as age is concerned, there are hardly any differences in the use of $[\mathrm{I}]$ and $[\mathrm{r}]$ in initial position. For $[\mathrm{I}]$, which is the most frequently used variant for all age-groups, the frequency decreases slightly throughout age. Overall [I] seems to slightly lose its popularity, while $[r]$ is becoming slightly more popular in the younger two age-groups. For $\mathrm{NE} / \mathrm{r} /$ in medial position the figures are as follows.

Table 25 - Realisation of $/ \mathrm{r} /$ in Medial Position

\begin{tabular}{|l|l|l|l|}
\hline & I & I & Total \\
\hline I & $76.7 \%(69)$ & $23.3 \%(21)$ & $100 \%(90)$ \\
\hline II & $77.8 \%(49)$ & $22.2 \%(14)$ & $100 \%(63)$ \\
\hline III & $84.4 \%(76)$ & $15.6 \%(14)$ & $100 \%(90)$ \\
\hline
\end{tabular}

The differences between the age-groups amount to eight per cent. The informants of agegroup I and II realise $/ r$ / as apical [r] in almost one out of four occurrences, while the oldest informants used it less. [I], which is the most frequent variant, is becoming less frequently used. The figures indicate that $[\mathrm{I}]$ is less often used by the younger informants. Apical [r], on the other hand, is becoming more popular in the younger agegroup.

Word-final / $\mathrm{In} /$ is of interest, since the informants show some variation in realising the combination of vowel and consonant. / $\mathrm{m} /$ occurs in verb forms ending in -ing, that is present participle and gerund, as well as in the words something and nothing. That there 
is variation between [II] and [In] is not a feature of NE alone, but of many other accents of English. The table below gives the figures for NE / In/.

Table 26 - Realisations of /In/

\begin{tabular}{|l|l|l|l|}
\hline & If & In & Total \\
\hline I & $38.6 \%(22)$ & $61.4 \%(35)$ & $100 \%(57)$ \\
\hline II & $27.5 \%(11)$ & $72.5 \%(29)$ & $100 \%(40)$ \\
\hline III & $70.2 \%(40)$ & $29.8 \%(17)$ & $100 \%(57)$ \\
\hline
\end{tabular}

The factor age influences the use of both variants of NE /In/. There are differences of more than 40 per cent. Not only in frequency, but also in terms of most frequently used variant, age-group I is different from the other two age-groups in that, for the oldest informants, [In] comes second in terms of frequency and is used a lot less. In age-group $\mathrm{III}, / \mathrm{In} /$ is realised as [In] in only one third of all occurrences.

The widest gap lies between the oldest and the middle informants. From age-group III to age-group II, the likelihood of [In] more than doubles. [In] is the most popular variant for both age-groups. In terms of use, $\mathrm{NE} / \mathrm{In} /$ is realised as [In] by the oldest informants in one third of occurrences, by the middle informants in three quarters, and by the youngest informants in two thirds.

The figures for [II] are, of course, the reverse of those for [In]. The oldest informants realise $\mathrm{NE} / \mathrm{In} /$ as [II] in more than two thirds of all occurrences, the middle informants use it in one quarter, and, for the youngest informants, [In] occurs in slightly more than one third of occurrences.

\section{Conclusion}

Languages change, and so does the accent of Neath. Apart from other factors, age influences the use of language in Neath. When looking at the phonemes and the variants with which they are realised, it becomes obvious that some factors have more influence than others. Age seems to be the most influential factor in NE as for many variants the percentage varies the most throughout age. There are differences of up to 60 per cent. The realisations of STRUT, BATH and START, FACE/STAY, GOAT/SNOW, NEAR, CURE, PLAYER, emPLOYER, FIRE, POWER, and the consonants alike have changed throughout age. Some variants are becoming more popular, others are being used less.

\section{References}

Cheshire, J. 2002. Sex and gender in variationist research. In Chambers, J. K., P. Trudgill and N. Schilling-Estes (eds.), The Handbook of Language Change and Variation. 423-443. Oxford: Blackwell.

Cheshire, J. 2005. Age and Generation Specific Use of Language. / Alters- und generationsspezifischer Sprachgebrauch. In Ammon, U., N. Dittmar, K. J. Mattheier (eds.), Sociolinguistics: An International Handbook of the Science of Language and 
Society - Soziolinguistik: Ein Internationales Handbuch Zur Wissenschaft Von Sprache und Gesellschaft. $2^{\text {nd }}$ revised (ed.). 1552 - 1563. Berlin: Walter de Gruyter.

Collins, B. and I. M. Mees. 1989. The Phonetics of Cardiff English. In N. Coupland (ed.), English in Wales. pp. 87-103. Clevedon, Philadelphia: Multilingual Matters.

Collins, B. and I. M. Mees. 2003. Practical Phonetics and Phonology. A resource book for students. London: Routledge.

Connolly, J. H. 1989. Port Talbot English. In N. Coupland (ed.), English in Wales. pp. 121-129. Clevedon, Philadelphia: Multilingual Matters.

Coulmas, F. (ed.) 1997. The Handbook of Sociolinguistics. Oxford: Blackwell.

Coupland, N. (ed.). 1989. English in Wales. Clevedon, Philadelphia: Multilingual Matters.

Eckert, P. 1997. Age as a Sociolinguistic Variable. In: F. Coulmas (ed.). The Handbook of Sociolinguistics. pp. 151-167 Oxford: Blackwell.

Evans, C., et al n.d. [1993], The Urban Dialect Questionnaire. Revised version. Swansea: privately publish(ed.)

Foulkes, P. and G. Docherty. (eds.). 1999. Urban Voices. Accent Studies in the British Isles. London: Arnold.

George, C. 1990. Community and Coal: an Investigation of the English-Language Dialect of the Rhondda Valleys. Mid Glamorgan. Unpublished PhD thesis: University of Swansea.

Hughes, A. and P. Trudgill. 1979. English Accents and Dialects. An Introduction to Social and Regional Varieties of British English. London: Arnold.

Mees, I. M. and B. Collins. 1999. Cardiff: a real-time study of glottalization. In Foulkes, P. and G. Docherty (eds.), Urban Voices. Accent Studies in the British Isles. pp. 185202.

Milroy, L. and M. Gordon. 2003. Sociolinguistics. Method and Interpretation. Oxford: Blackwell Publishing.

Parry, D. 1985. On Producing a Linguistic Atlas: The Survey of Anglo-Welsh Dialects. In Kirk, J. M., S. Sanderson and J. D. A. Widdowson (eds.), Studies in Linguistic Geography. The Dialects of English in Britain and Ireland. pp. 51-66. London: Croom Helm.

Parry, D. 1999. Grammar and Glossary of the Conservative Anglo-Welsh Dialects of Rural Wales. Sheffield: National Centre for English Cultural Tradition.

Parry, D. n.d. [1977]. (ed.). The Survey of Anglo-Welsh Dialects. Vol. I.: The South-East. Swansea: privately publish(ed.)

Parry, D. n.d. [1979]. The Survey of Anglo-Welsh Dialects. Vol. 2.: The South-West. Swansea: privately published.

Penhallurick, R. 2004. Welsh English: phonology. In Schneider, E. W., K. Burridge, B. Kortmann, R. Mesthrie and C. Upton (eds.), A Handbook of Varieties of English. Volume 1: Phonology. pp. 98-112 Berlin: Mouton de Gruyter.

Penhallurick, R. (ed.). 2000. Debating Dialect : Essays on the Philosophy of Dialect Study. Cardiff: University of Wales Press.

Podhovnik E. 1995. Phonology of Swansea English. Diplomarbeit zur Erlangung des Titels Magister phil. Graz: Karl-Franzens-Universität.

Podhovnik, E. 2008. The Phonology of Neath English. A Socio-dialectological Survey. Unpublished PhD Thesis. Swansea: University of Wales. 
Schneider, E. W., Burridge, K., Kortmann, B., Mesthrie R. and Upton, C. (eds.) 2004. A Handbook of Varieties of English. Volume 1: Phonology. Berlin: Mouton de Gruyter.

Tench, P. 1989. The Pronunciation of English in Abercrave. In Coupland, N. (ed.), English in Wales. pp. 130-141. Clevedon, Philadelphia: Multilingual Matters.

Thomas, A. R. 1984. Welsh English. In Trudgill, P. (ed.), Language in the British Isles. pp. 178-194. Cambridge: CUP.

Trudgill, P. (ed.). 1984. Language in the British Isles. Cambridge: CUP.

Upton, C. 2000. Maintaining the Standard. A job for dialectologists. In Penhallurick, R. (ed.), Debating Dialect : Essays on the Philosophy of Dialect Study. pp. 43-64. Cardiff: University of Wales Press.

Upton, C. 2004. Received Pronunciation. In Schneider, E. W, K. Burridge, B. Kortmann, R. Mesthrie and C. Upton (eds.), A Handbook of Varieties of English. Volume I: Phonology. pp. 217-230. Berlin: Mouton de Gruyter.

Walters, J. R. 1999. A study of the segmental and supra-segmental phonology of Rhondda Valleys English. Unpublished PhD thesis, University of Glamorgan.

Wells, J. C. 1982a. Accents of English 1. An Introduction. Cambridge: CUP.

Wells, J. C. 1982b. Accents of English 2. The British Isles. Cambridge: CUP.

Welsh Office 1998. Statistics for Assembly Areas 1998. HMSO. 